\title{
Human Security Analysis as a Framework for Value-Oriented Governance - the example of climate change ${ }^{i}$
}

\author{
Des Gasper - International Institute of Social Studies (The Hague), of Erasmus University
} Rotterdam, Netherlands - October 2014

\section{Abstract}

'Good governance' may be viewed as governance which 'Good governance' may be viewed as feffectively promotes ectively promotes human rights, human security and human development. The phuman rights, human security analysis, which in certain ways offers an integration of these 'human' po security and human 'social' orientation, combining a personfocus with systematic investigation development. The stems of all sorts: physical, cultural, organizational. The importance of such analysis is illustrated through the example of climate change impacts and adaptation. The paper presents applications of a human security framework in governance, for policy analysis, planning and evaluation issues in climate change and other fields and from around the world. The concluding section suggests that human security analysis may provide a way to apply insights from social quality analysis to detailed case investigation and policy analysis, while reducing macro-sociological abstraction and neglect of the natural environment.

\section{Introduction}

Social quality analysts need to think in terms of instituted and socially legitimate systems of governance. Assessment of social quality need to be essayed through instituted mechanisms of social accountability, not only through ad hoc mechanisms of evaluation; and needs to be in terms of legitimate established value-principles, not only through criteria independently formulated by the evaluators. Human rights principles as established in internationally accepted conventions could be central here. The 'democracy audits' of IDEA, the International Institute for Democracy and Electoral Assistance, for example, centre on applying human rights philosophy, including those human rights principles that cannot readily be turned into precisely justiciable rights but which should still carry weight in institutional design and practice (Beetham 2004; Beetham et al. 2008). Human security analysis is an essential sister endeavour.

Human rights standards and principles are often opposed by claims of 'security', presented as being the overriding requirements of the national collectivity. We should ask though about 'security for whom?' and 'security of which values for which people?'. Too often the security of the privileges of minorities, concealed behind a language of 'national security' or of the needs of 'the economy' or of equivalent abstracted notions, is given priority over the security of fulfilment of basic needs, basic rights and basic values for ordinary people. The work on 'human security' which has grown during the past two decades, as a flexible and broaderranging partner of human rights thinking (Estrada-Tanck 2013), tries to counteract such 
concealment and to place the spotlight on the lives of ordinary people and on respect for their basic needs and rights. Growing bodies of work use a human security perspective for investigating global environmental change, livelihoods, migration, conflict, crime, gender issues and psychological insecurity (see e.g. Gasper and Gomez 2014 for an overview). After several years of discussion a shared understanding of the approach and its contributions was endorsed in late 2012 by the United Nations General Assembly. ${ }^{\text {ii }}$ This paper reviews the character of the approach, discusses experiences and issues in converting its general framework into practical plans, and presents a case for social quality research to relate itself to this work.

The next section of the paper introduces the idea of 'good governance' as governance which effectively promotes values of human rights, human security and human development. The subsequent two sections discuss these linked 'human' frameworks, with special reference to human security analysis, and then illustrate the importance of the latter for issues of climate change impacts and adaptation. The penultimate section looks at application of a human security framework in planning and evaluation, for climate change response as well as more broadly. The final section returns to the relationship of this framework to social quality analysis, and sums up.

An earlier piece in this journal (Gasper 2011a) offered a preliminary comparison of discourses of human development, human security and social quality. It suggested that partnership of the social quality approach with these 'human' approaches was possible and relevant. Both sides try to bring analytical and policy integration across conventional sectoral and disciplinary boundaries, with concern for priority criteria of human well-being (see also Gasper et al. 2013). The human security perspective in particular combines main elements of human development thinking and human rights analysis with some additional features, and presents one integration of 'human' and 'social' perspectives. Whereas 'human development' work arose originally as an enrichment of conventional welfare economics, and social quality analysis has arisen out of classic sociology including from concepts from Durkheim, Parsons, Habermas et al., human security analysis can be seen as an extension of the sort of framing that is characteristic of social anthropology (Gasper 2013a). It combines a person-focus with systematic investigation of the environing systems of all sorts: physical, cultural, organizational. It provides a way to apply insights from social quality analysis (SQA) in detailed case investigation and policy analysis, while balancing SQA's macro-sociological abstraction and relative neglect of the natural environment. Whereas the earlier paper (Gasper 2011a) was conceptual, the present paper focuses on applications of a human security approach for governance, including especially in policy analysis. 


\section{Human-oriented Governance}

The Millennium Development Goals (MDGs) have given a major impetus to steering national and international governance beyond only supporting economic expansion, and to focusing centrally on protection and promotion of basic human interests. They have done so though in a rather simplistic standardized way, and need to be refined to give more space for situationspecific analyses and accountability processes. Paralleling the MDGs has been a One-Style-FitsAll syndrome of promotion of a single model of governance by some leading aid donors. That syndrome led for many years to external funders kicking hedgehog- or turtle-like governments, without much effect. More appropriate and more effective is an approach that respects national specificity, national sovereignty, national-level knowledge and energies, but that provides an inspiring general vision and a framework for principled and creative local analysis.

The idea that there could be a single universally appropriate procedural and institutional framework for governance has been a fantasy of some international funding organisations and analysts during the past generation. The fantasy survived partly because of the vagueness around the term 'governance', and the failure to distinguish between: first, very general notions (Oberbegriffen in German; Colebatch 2009) that cover all forms of managing behaviour - for example notions that refer to all rule-setting and rule-application or to all exercises in guiding behaviour or all exercises in governing; second, more specific notions (Gegenbegriffen) that exclude some types of governing and are defined in contradistinction to those; and third, the idea of 'good governance', which should not be equated with either of the first two. Too often the failure to distinguish has meant that authors try to capture the general aura of authority and sophistication that attaches to the term 'governance', and to transfer both the aura and the term to just one particular set of arrangements for governing-for example, working through multi-stakeholder networks or indirect 'steering' by a government or provision of support for private businesses-and to advocate that particular set alone as constituting 'good governance' universally.

Table 1 integrates and compares a series of these contemporary definitions of governance. It adds an intermediate level of specificity, illustrated by the well-known definition of governance as the ordering of the interplay of the three actors/'estates': State, business and civil society, and by the popular visualization of that interplay in the 'governance triangle'.

Confusion arises from thinking of governance only in terms of the more specific Gegenbegriffen, for example equating governance to co-determination by state-societybusiness networks. Recognition that governance typically does and should involve numerous different arrangements, should be partnered by an evaluative picture of what are the shared general purposes by which the diverse possible arrangements are to be assessed, selected and reformed. The United Nations frameworks of human rights, human development and human security provide such a conception. Thus in contrast to notions of good governance which 
assert that a particular concrete form of governance arrangements constitutes good governance for all countries and all circumstances, a more general and suitable notion of good governance is: governance that furthers human rights, human security and human development. This notion is highlighted in Table 1 and adopted in this paper. The paper explores such an agenda: how to investigate the determinants of and requirements for human security, per situation and per group.

\section{Table 1: Definitions of Governance}

\begin{tabular}{|c|c|c|c|}
\hline $\begin{array}{l}\text { DEFINITIONS OF } \\
\text { GOVERNANCE }\end{array}$ & Broader versions & Narrower version & $\begin{array}{l}\text { Notions of good } \\
\text { governance }\end{array}$ \\
\hline $\begin{array}{l}\text { More } \\
\text { general/abstract } \\
\text { (Oberbegriff = master } \\
\text { concept }- \text { see } \\
\text { Colebatch 2009) }\end{array}$ & $\begin{array}{l}\text { 'Conduct of conduct' } \\
=\text { guiding of } \\
\text { behaviour, by use of } \\
\text { diverse tools } \\
\text { (governmentality). } \\
\text { Governing, in all its } \\
\text { forms }\end{array}$ & $\begin{array}{l}\text { Guiding of behavior by } \\
\text { use of setting and } \\
\text { applying rules }\end{array}$ & $\begin{array}{l}\text { Governing / Guiding of } \\
\text { behavior, that well } \\
\text { serve(s) human security, } \\
\text { human rights and human } \\
\text { development }\end{array}$ \\
\hline $\begin{array}{l}\text { Intermediate degree } \\
\text { of generality }\end{array}$ & $\begin{array}{l}\text { Ordering of the } \\
\text { interplay of State, } \\
\text { business and civil } \\
\text { society: the basic } \\
\text { 'governance triangle' }\end{array}$ & $\begin{array}{l}\text { Snidal \& Abbott 2009's more } \\
\text { specified governance } \\
\text { triangle that indicates seven } \\
\text { distinct spaces of control, of } \\
\text { which four involve joint } \\
\text { control (State \& business; } \\
\text { State \& civil society; } \\
\text { business \& civil society; all } \\
\text { three actors) }\end{array}$ & $\begin{array}{l}\text { Assertion of particular } \\
\text { spaces of control, and/or } \\
\text { particular modes of } \\
\text { operating in particular } \\
\text { spaces, as being better }\end{array}$ \\
\hline $\begin{array}{l}\text { More } \\
\text { specific/concrete } \\
\text { (Gegenbegriff - a } \\
\text { concept that highlights } \\
\text { one case, contrasted } \\
\text { with other cases) }\end{array}$ & $\begin{array}{l}\text { Steering (not rowing) } \\
\text { by government } \\
\text { Governing with and } \\
\text { through networks } \\
\text { (not through } \\
\text { hierarchy) }\end{array}$ & $\begin{array}{l}\text { Setting the operating } \\
\text { environment for markets }\end{array}$ & $\begin{array}{l}\text { Presentation of steering / } \\
\text { network governance / } \\
\text { support of markets as } \\
\text { being the universally } \\
\text { appropriate form)s) for } \\
\text { governance }\end{array}$ \\
\hline
\end{tabular}

[Source: author] 


\section{Human Security and Related Discourses}

..anyone who speaks forcefully for human rights but does nothing about human security and human development-or vice versa-undermines both his credibility and his cause. So let us speak with one voice on all three issues... (Kofi Annan 2006)

The purposes and principles endorsed by the leaders of the world's governments in the Millennium Declaration of 2000 extended well beyond only the MDGs, and reflected more broadly the values of human dignity that have been expressed across several decades via the United Nations through the ideas of human rights, basic human needs, human development and human security.iii The founding rationale of the United Nations system from the 1940s onwards concerns not just the fundamental importance but also the interconnectedness of peace, human rights and socio-economic development. Its core theme can thus be summarized as human security. This underlying unity of its concerns was re-articulated by, for example, Kofi Annan while he was UN Secretary General (1997-2006), and before him by the Pakistani economist Mahbub ul Haq (1934-1998). Haq, the main creator of the theme of 'human security' using that particular label, in the 1994 Human Development Report which he led, had not coincidentally earlier headed the World Bank's basic needs programmes in the 1970s and founded the United Nations Development Programme (UNDP)'s Human Development Report Office in 1989 (Gasper 2011b).

Human security thinking takes forward and refines the theme of basic-needs priorities. We see this in its frequent use of the summary labels 'freedom from want', 'freedom from fear' and 'freedom to live in dignity'. Basic human needs are understood as more than only the 'freedom from want' basic material needs. The three 'freedoms' labels came into prominence in the 1940s, during the process of defining purposes for the envisaged or emergent United Nations system and new arrangements for global governance after the disasters of war and global economic depression in much of the first half of the $20^{\text {th }}$ century. So the human security theme is not new. It was re-emphasised though by Haq and others, to complement the themes of human rights, which had been increasingly prominent since the 1948 Universal Declaration, and of human development, which Haq had launched for UNDP in 1990. The three provide partly different selections and emphases but from within a single family of ideas.

As formulated by UNDP under the influence of Indian economist Amartya Sen, 'human development' means expansion of the attainable doings and beings which people have good reason to value - in other words, expansion of their valuable freedoms and capacities (Sen 1999; Haq 1999). This reflects that development is not only about economic growth; for while economic growth is one important possible means towards human well-being and fulfilment it does not necessarily and always promote those values and it excludes many important aspects of life. Within the vast scope of this field of 'human development', the highlighting of basic 
needs as priorities to be secured-human security objectives-helps to provide direction in public policy.

The required form for these human security objectives is often as a human right-such as when we talk of right to life, right to (sufficient) food, and right to basic health. As defined by the Global Environmental Change \& Human Security research program (1999-2010) that worked as part of the International Human Dimensions Program on climate change, human security is where 'individuals and communities have the options necessary to end, mitigate or [sufficiently] adapt to threats to their human, social and environmental rights; have the capacity and freedom to exercise these options; and actively participate in pursuing these options' (http://www.gdrc.org/sustdev/husec/Definitions.pdf).

Across this connected family of discourses-human development, human needs, human rights, human security (Gasper 2007) - the following features deserve underlining. First, the discourses use a 'zoom lens' to look at how individual people, families and groups actually live and can live, including looking at their attainable, reasoningly valued, opportunities. This is the 'human development' reconceptualization of the meaning of 'development' and it rests on a human rights concern for each individual person. Second, they explore the risks and pressures to which people's lives are subject within trans-disciplinary and global systems of interconnection. Thus they use at the same time a 'wide-angle lens' that extends our field of vision beyond the boundaries to analysis that are conventionally set by national frontiers and academic disciplinary divisions.

These two features are jointly highlighted in the work on human security, which emphasises the systemic interconnections (see the second feature) that become reflected in terms of impacts on individual lives (see the first feature) (CHS 2003, UNESCO 2008, Leichenko \& O'Brien 2008, Gasper 2013b). So, in the 'human security' elaboration of the agenda of 'human development' we try to look at the whole reality of individual people's lives, as affected not only by those factors conventionally measured and described by any one scientific discipline but by the intersecting ensemble of all factors (UNDP 1994; Leichenko and O'Brien 2008). 'Intersection' means more than merely addition; so Parthasarathy writes of 'refraction' and 'prismatic vulnerability'. 'The same axis of discrimination or inequality such as gender, ethnicity, class or caste [or residential location, age, (dis)ability, form of livelihood, or degree of social inclusion/exclusion] may get refracted by different hazards in very different forms or levels of vulnerability. [And] the same disaster may refract different types of inequality into distinct vulnerability situations and outcomes.' (Parthasarathy 2013: 52).

So human security analysis's concern with the nature and sources of security and insecurity in daily lives leads it to investigate 'which qualities matter?' for people and how lives are affected by the intersections of diverse factors-economic, political, medical, gender, class, race, religious, sexual identity, and more-that jointly structure and affect people's experiences. A human security framework thereby helps to motivate listening-oriented 
fieldwork about daily lives. Often such fieldwork presents perspectives different from the expectations and perceptions of conventional 'security providers'. A book-length study of human (in)security in Bangladesh illustrates this vividly (Safeworld 2008).

In a survey of 2000 households carried out in 2007 by the Research Division of BRAC, many more people identified 'freedom from want' issues as big problems-poverty (69 per cent), unemployment (65 percent), provision of utilities (56 percent) and vulnerability to natural disasters (51 percent) - than chose to highlight issues that are conventionally placed under a 'freedom from fear' heading (including crime, extortion, and availability of firearms).

...the level of insecurity relating to 'freedom from fear' is perceived as being relatively low compared to 'freedom from want' [issues]. Bangladeshis consider issues such as poverty, employment, food security and health to be much greater concerns than crime. (Saferworld 2008: 104.)

...With 50 percent of Bangladeshis living below the poverty line, poverty and unemployment are the greatest concerns for most people. Poverty underlies many other problems. ... [including] access [to] basic services such as healthcare, sanitation and education. Poverty and unemployment are also seen as being the two most important drivers of crime and injustice. (Saferworld 2008: ii).

Similarly, when the interviews asked which sources of threat made people feel insecure:

.... [n]atural disasters were the most common concern (53 percent), followed closely by a lack of healthcare (48 percent). ... Worries about natural disasters are a much greater concern in rural areas [58 percent in rural areas, versus 37 percent in urban areas]... where the two most frequent responses are crime and drug abuse. (Saferworld 2008: ii)

Even when people were asked about freedom from fear, specifically about who and what are the providers of security here, the most common responses were not the conventional security apparatuses: '...education institutions (43 percent) [and] NGOs/microfinance institutions (34 percent) [ranked considerably above] police stations (28 percent), Union Parishads /municipalities (28 percent) and hospitals/healthcare facilities (20 percent). These results show that Bangladeshis understand human security to be about much more than crime and justice.' (Saferworld 2008: vii).

'Natural disasters' were already in 2007 the greatest felt threat, and climate change is likely to seriously further increase their frequency and magnitude. By the end of this century, 'by some estimates, a one metre sea-level rise will submerge about one-third of the total area of Bangladesh, thereby uprooting 25-30 million of our people... They are most likely to become refugees of climate change', declared the then head of government (Ahmed 2007). Even much smaller rises could uproot large numbers of people, as can the increasingly frequent extreme weather events (IPCC 2012). 'Despite this, little serious analysis is available of possible scenarios for the effects of climate change on human security in Bangladesh', at least as of a few years 
ago, declared the Saferworld report (2008: xvi). The sheer scale of the challenges faced and of the demands for societal reorientation may exceed the capacity of business-as-usual politics, especially the bitterly divided party politics of Bangladesh. In addition, the relative lack of attention may reflect that the people at risk are predominantly from poorer groups, who are those on the lands most at risk of flooding, those with the least robust houses, those who feel they cannot risk to leave their animals unattended even during a flood or cyclone. ${ }^{\text {iv }}$

Still less attention to these threats is likely in many of the global power centres implicated in the greenhouse gas emissions, past and present, that drive the main climate trends. From those centres even the megalopolis of Dhaka, capital of Bangladesh and home to an estimated 14.4 million inhabitants in 2013, may barely register. The influential Mike Hulme, founder director of the Tyndall Centre for Climate Change Research in the UK and founder editor of the journal Wiley Interdisciplinary Reviews (WIREs) Climate Change, uses 'Dacca', the pre-1982 name (Hulme 2009). Gilman et al. (2011), writing in The Oxford Handbook of Climate Change and Society persistently and exclusively speak of 'Dakka'.

Strengthening accountability at both global scale and national scale requires a change in perspective. Accountability is important because, amongst other reasons, unaccountable power-holders are not perfectly diligent, perfectly benevolent, perfectly informed and perfectly competent. Social accountability, transparency and participation require more though than only procedures for reporting and channels for communication. They require relevant ideas and principles, regarding the criteria in terms of which power-holders are to be held accountable. Perfect procedures remain empty if there are no notions about what-and who-should count and be counted. A human security framework can valuably contribute here.

\section{Focusing evaluation and accountability: the case of climate change}

Compared to general human development analysis, which considers the entire range of attainable values, the focus in human security analysis is on the basics of being human. This narrower focus can in some respects generate more insight. A focus on basics, of various sorts, including on subjectivity and feelings, deepens recognition of the (threatened) dignity and lived realities of individuals. Security and insecurity are inextricably concepts that have both objective and subjective versions. Further, human security thinking-in contrast to some work using only ideas of human rights or human development-leads to an emphasis also on the human species, not only individuals; and to a stress on pervasive interconnection, which grows out of its attention to the complex causation of threats and opportunities.

These themes are all especially apposite in relation to climate change, which has begun to seriously affect many parts of the world, including much of South and South East Asia, not least Bangladesh (IPCC 2014). Much of the discussion of climate change's possible and likely impacts remains too abstract and dehumanized. It diminishes the significance of particular shifts in 
conditions for some particular groups of people, especially when those shifts interact with other conditions and trends and generate chains of knock-on effects. '...studies show that poverty and hunger are likely in places where multiple stressors [such as economic policy reforms, urban expansion, agricultural restructuring, etc.] interact with climate change (Eakin 2005; Leary et al. 2006; Leichenko and O'Brien 2008; Ziervogel et al. 2006)' (Barnett 2011: 273). Besides the already evident disruptive shift in average timing and character of the monsoon in Bangladesh, Routledge (2011) notes that increasingly frequent and intense extreme weather events will have multiple impacts. As a result of the 2007 Cyclone Sidr followed by the 2009 Cyclone Aila, for example, some women in Satkhira district in southern Bangladesh were having to travel four hours a day to collect fresh water (ibid.: 389). Such 'one-off' climate events can have long term consequences, for example forcing out-migration and thereby affecting much else, such as the relations between Bangladesh and India (Gilman et al. 2011; Routledge 2011).

Correspondingly, much of the discussion of policy for climate change adaptation has also remained too abstract:

'...in climate change terms [adaptation] means actions that are taken to reduce vulnerability. ... The precise goals of adaptation are rarely articulated, which is to say that it is rare to see an academic or policy discourse about adaptation which identifies the specific risks that adaptation seeks to avoid, and to whom those risks most apply (such as, for example, the risk of increased malnutrition among women in the highlands of Papua New Guinea). For this reason, among others, adaptation [policy] will not necessarily be effective, efficient, or equitable....' (Barnett 2011: 270).

When real specific people are not foregrounded, discussion becomes dominated by the 'needs' of things, such as of physical structures or 'the economy', and downgrades the needs of the mass of poorer people, who are those who are by far the most at risk. Thus, "the term "human" in the concept human security should be understood as an opportunity to expose practices and structures of difference and marginalization rather than to mask them or subsume them under the umbrella of a single "humanity" " (Elliott 2013: 168). Human security thinking 'specifies clearly that climate change poses risks to core needs, rights, and values of [particular] people and local communities, and in so doing establishes some clearer goals for and metrics to measure the success of decisions about mitigation and adaptation' (Barnett 2011: 271).

Climate change is an extreme case, but not a marginal case. It will become centrally important for the countries of Asia, Africa, Latin America and the Pacific during the generation ahead, and is already centrally important for many socially marginal groups. It illustrates in extreme degree the need for intellectual and institutional frameworks that pay attention to socially marginal people, frameworks that help to make power systems and power holders take account of these fellow citizens (national and global) and be accountable to them too. This accountability will require enormous efforts of communication, publicity and pressure, to open eyes and ears and increase sympathetic and serious attention. Routledge (2011) presents the 
example of the work of the Bangladesh Krishok Federation for landless peasants, at various levels: locally and nationally inside Bangladesh; in the South Asia and wider Asia regions; and globally, for example as a member of the La Via Campesina movement. It campaigns for not only national food security but also local food sovereignty. Lipschutz and McKendry (2011) examine how, at global level, networks of groups like Climate Action Network force some degree of transparency and accountability upon inter-governmental climate change negotiations.

The required cooperation between actors at the various levels-global, national, localrelies upon having shared, clear, motivating and mutually acceptable 'languages' for the sustained communication, publicity and pressure, languages that are meaningful for all the widely separated parties across divisions that are both physical and cultural. For these roles, the languages of human security and human rights have merits of accessibility, legitimacy and appropriate forcefulness (Gasper 2012, 2015).

In contrast, political democracy as such shows no clear favourable correlation with the governance capacities and moral imagination required for equitable and effective responses to climate change challenges. This is notably true for the more markedly 'liberal' and marketcentred democracies of the USA, Canada, and Australia, including when we compare them to non-liberal democratic China (Burnell 2012; Held et al. 2013). Even if the performance of countries classified as democracies were a bit better than average, their average performance is still poor. However, there are important performance variations between supposedly similar countries, which reveals the influence of and interaction with many other factors besides democratic structures. This shows the need for detailed retrospective case studies and prospective scenarios, indeed for every country and locality, given climate change's enormous importance (see e.g., Dyer 2010; Held et al. 2013; Moran 2011).

There remain reasons to think that some aspects of democracy are important for equity and effectiveness in responses to climate change. Even if we accept that full deliberative democracy is not a feasible target, elements of participation and of deliberation are important for wellinformed, legitimate and equitable decision-making, and thus for coping better with the stresses produced by climate change. They can reduce the risks of conflict that could lead on to chaos. Burnell (2012) suggests that while democracy may be weak in promoting climate change mitigation, it is helpful in adaptation. It may be important too for due consideration of the value choices involved in deciding responses to climate change, regarding who will bear costs, who bears which risks, and which values will be prioritised. Further, as mentioned earlier, democracy should not be conceived of as only adult franchise in a market-dominated society. It can better be viewed as involving a human rights based approach that respects the dignity of all persons, as shown in the work of IDEA (www.idea.int) and David Beetham (Beetham and Boyle 1996; Beetham et al. 2008). ${ }^{v}$ 
For climate change, a central issue about societal responsibility is: What determines the capacity of a society/state to adopt a broad and long-run perspective that respects the rights and interests of 1 . Children (who otherwise typically have little voice), 2. Future generations (who have no voice), and 3. People in other countries (who have little or no voice outside their own nation-state). These are the groups who, in addition to and intersecting with the most socially marginal and vulnerable groups, form the bulk of those most affected by the climate changes caused by present day consumer societies' way of life. Inhibiting the taking of responsibility for the effects of one's way of life are various factors:- the uncertainties and lags between actions and effects, hostility towards other countries, and the influences of individual mortality and indifference to others, including indifference to the future (epitomized by the quip: 'What did the future ever do for me?'). Market systems using market rates of interest heavily discount the lives of future generations and also the old age of presently-born children; nation-based systems may not consider the rights and interests of people in other countries; and market-based national systems can heavily discount all of these groups.

Determinants of how broadly or narrowly oriented is behaviour in a society, and how shortterm or long-term oriented, can include the nature and quality of its deliberative institutions and structures. Amartya Sen argues that provision of public information counters selfish indifference to the suffering of others (e.g., Sen 1999), through arousal of sympathy or at least through 'naming and shaming' in relation to a society's failures if this reduces the authority and/or electoral chances of inert ruling groups. But this may sometimes work only in extreme cases, and even then not always: in India routine starvation by some marginal groups (e.g., tribal peoples) unfortunately does not become a shaming political issue. Appropriate societal 'language(s)' and systems of thought are important as preconditions for the effectiveness of providing information. Particularly important is the degree to which the ability and habit to sympathetically imagine the lives of others is cultivated - what Martha Nussbaum (1997) calls 'the narrative imagination'.

The acclaimed 2009 book by leading British climate researcher Mike Hulme, Why We Disagree About Climate Change, explores in each chapter a suggested reason why people disagree about climate change. Hulme's narrative imagination does not range far, and missing in its 400 pages is much perspective from or for the global South. He notes that which risks get stressed depends on who has voice, and he claims that those who can and do exercise 'voice' are the Green affluent classes in the North (Ch.6: The Things We Fear). Implied then as lacking voice are the poor in Africa, Asia and the Pacific; but the book does not highlight the risks they face. Instead Hulme quotes Steve Yearley's view that 'we are concerned about climate change not so much because of any substantive dimunition of human or non-human welfare that might ensue, but because of the strong element of symbolism involved' (Hulme, 2009: 343). The 'we' that he is preoccupied with encompasses the rich, especially in the global North, but not ordinary Bangladeshis, Ethiopians or Pacific islanders. 
The prospective costs discussed in Hulme's chapter on valuation thus concern the loss of bits of the natural environment and associated aesthetic values (pp. 114-5, 134): what is 'the worth of a songbird', he asks (p.134) ? The examples are not about retaining one's life and health. Yet, to quote a projection in the World Development Report 2010, business-as-usual global warming might bring another three million deaths per year from malnutrition by 2100 (World Bank 2010: 5). The associated rights-based arguments against global warming concern current generations alive in the South, not only the unborn, for the negative impacts will not start only in 2100. Bangladeshi and Ethiopian babies today face lives of seriously increased risk of fundamental dangers. Hulme moves on to present the arguments for using a high discount rate that downgrades the importance of future generations. The arguments give no weight to the chance that some members of future generations (especially those in Bangladesh and Ethiopia more than those in Britain) may be at risk of devastation, not merely of reduction of a super-affluence far above present-day standards (Hulme 2009: 122). His discussion of chances of disaster (p.123) does not ask disaster for whom. Its examples are airport security and the risk of a cooker malfunctioning; not drought or flood or famine affecting low-income and vulnerable families who are unable to cope with them.

Hulme treats 'development' in a separate chapter. After noting that issues look different when seen from 'Dacca' (p.252), he spends the chapter on a re-run of the Bruntland-andbeyond debates on 'sustainable development', territory that was covered under different labels in his earlier chapters, not on an attempt to see how the world actually looks like from Dhaka (the name adopted in 1982). ${ }^{\text {vi }}$ Bangladesh is a leading centre for the movement around climate justice, and for preparations for adaptation against prospective sea level rises, increased rainfall variability, increased glacial melt, and more frequent tropical storms. It is not mentioned in Hulme's twelve page index, nor in his Preface's list of the many countries he visited. ${ }^{\text {vii }}$ Forty years ago, during a major famine in Bangladesh, the philosopher Peter Singer raised the profile of the field of global ethics by arguing that rich individuals and rich countries have a moral obligation to help if they can, even if they have no immediate causal responsibility for the famine. Climate change generates much stronger claims, for the actions of rich countries and rich individuals affect the climate in poor countries, jeopardise the lives and livelihoods of their peoples, and imply obligations to avoid, prevent and compensate for damage caused. Bangladeshi scientist Atiq Rahman argues that: 'From now on we need to have a system where, for every 10,000 tonnes of carbon you emit, you have to take a Bangladeshi family to live with you. 'viii Hulme, in contrast, presents the world as viewed from the rich North, looking down on or simply overlooking 'Dacca'. I suggest that explicit argumentation in terms of human security and human rights could help to counteract this sort of myopia and to strengthen national, global and personal accountability. 


\section{Operationalising Human Security Ideas: levels of analysis and action}

In the first decade after the launch of the human security concept in the 1994 Human Development Report (HDR), disputes over the concept included arguments over what range of threats should be considered in terms of the language of 'security'. Some critics of the 'human security' notion claimed that the term 'security' was, and should be, linked exclusively to state security. They argued that security is a term for prioritization, and that priority must go to the security of the national state since achievement of all other objectives depends upon this, as the state (supposedly) ensures the conditions required for pursuit of everything else. Some other critics accepted a notion of 'human security' that refers to security in priority aspects of people's lives, but claimed that a broad interpretation here will lead to analytical confusion, unmanageability and lack of sufficient policy focus, so that 'human security' should only refer to people's safety from intentional physical violence (e.g., MacFarlane and Kheong 2006). Gradually acceptance has spread, reflected in the UN General Assembly's 2012 resolution, that, first, state security is only a means that does not always and necessarily promote people's security, for which much else is required, so that independent attention to human security, the security of persons, is essential; second, that prioritization, and hence the term 'security', apply and have always applied to much more than physical safety, including to food security, 'social security', livelihood security, environmental security and more; and third, that what are relevant priorities must be a matter partly for situation-specific analysis and political choice in each given time and place. (See also, e.g., the surveys in: UNESCO 2008; UN Secretary-General 2010; Gasper and Gomez 2014.)

Much work has emerged on how to convert human security thinking from a stimulating general conception into practical additions to the tools of governance. Initially after the 1994 HDR most attempts to apply the concept tended to stick to a few key ideas: ${ }^{\text {ix }}$ a people-centered focus, with attention to freedoms from fear and from indignity as well as from material want; and typically a concern with seven areas of security/insecurity specified in the 1994 Report: economic, food, health, environmental, personal, community and political security/insecurity. Over time, more and more studies do not analyse in terms of these seven areas, and instead focus and formulate in terms of the distinctive challenges encountered in the specific situation considered, though some studies still find the checklist of seven areas a helpful guideline that ensures broad attention and helps comparability across studies.

The 2001-3 Commission on Human Security chaired by Sadako Ogata and Amartya Sen, that reported to the UN Secretary-General, used the idea of priority for a 'vital core' of freedoms and rights, and acceptance that this would inevitably be specified in a way that was partly relative to a particular place and time (CHS 2003). Barnett explains how the 'idea of a "vital core" recognizes also that there are some non-instrumental values (such as love, sense of community, and identity) that are critical to a meaningful life, and which are neither basic 
needs (in the [economic] development sense of this term) nor necessarily human rights (in the legal sense of the term)' (Barnett 2011: 269). The Commission underlined also the importance of empowerment, not only the protection, treatment and promotion of security by others. Ideas of empowerment and securitability -- ability to defend and promote one's own security (a term introduced by the Latvia national study; UNDP 2003) -- have thus become prominent in human security discussion, together with the perceptions that human rights are key policy instruments in addition to being policy goals and that prevention is more important than palliation. The Latvia study highlighted also the idea of a 'constellation of providers', not only a single provider, introducing a complex governance perspective with attention to many different parts of government, mass media, self-help, family help, and private sector contributions.

We see thus an evolution in discussion, from the questions of 'Security for whom?', 'Security of which values?', and 'Security against which threats?', to consideration also of the operational questions of 'Security provided by whom?', 'Security through which instruments?', 'How much security?' and 'Security as perceived by whom?'. The details of operationalization are diverse and connect to the specialist areas concerned, like housing, pensions or climate change adaptation. A selection from the many published examples is given in the bibliography. Here we will look especially at examples from a series of Human Development Reports and from surveys of climate change governance.

'Operationalise' can mean various things, from narrower to broader: 1 . Measure; 2. Institutionalise/design at project level; 3. Institutionalise/design at strategy level (as a sector strategy, or a multi- and cross-sector strategy); 4. Institutionalise in one's entire approach, from the broad structuring of perception and motivation, through agenda-setting and framing, to detailed policy analysis and evaluation. So operationalisation should not be equated to measurement alone. Even so, the latter is important and can be very fruitful. Numerous human security indexes have been devised, for example for worldwide comparisons in some basic dimensions, as in Hastings' work for the UN Economic and Social Commission for Asia and the Pacific (Hastings 2010), and tailor-made indices for particular local situations, as in various national Human Development Reports (e.g. for Benin: UNDP 2011) and in the Philippines (Gomez 2011). Scholars in Bangladesh have developed a human security index for South Asia (Khan and Sabur 2011). A frequent finding in such exercises is large divergence between 'objective' (expert-assessed) and 'subjective' (local resident assessed) measures of security. Resident-assessed estimates of crime, for example, are frequently far higher than expert measures. Further research may vindicate either, or neither. Local residents sometimes stress dimensions that are not highlighted in 'expert' studies, as we saw from Bangladesh.

Operationalisation in project design has been pursued for years by the UN Trust Fund for Human Security (UNTFHS 2009; Gomez 2012). Operationalisation in sector-level strategy is illustrated by work led by Mary Kaldor on reorienting the 'security sector' (armed forces, police, 
other 'security services'), to respect physical security concerns for ordinary people (e.g. Glasius and Kaldor 2005); and by work in the Philippines done for its Human Security Act (Gomez 2011).

Attempts to collect lessons from the past two decades' experience include a series of regional surveys led by UNESCO (e.g., Burgess et al., 2007) and the resulting global synthesis report (UNESCO 2008), and two reviews of the many national and regional human development reports which have consciously adopted a human security approach: a 2006 review by Jolly and BasuRay $(2006,2007)$ and a recent update by Gomez et al. (2013). The study led by Jolly looked at the book-length studies prepared for UNDP in Afghanistan, Bangladesh, Bulgaria, Estonia, Kyrgyzstan, Latvia, Lesotho, Macedonia, Moldova, Mozambique, Philippines, Sierra Leone, Solomon Islands, and Timor-Leste. It examined how far were criticisms that had been voiced against human security thinking confirmed by these reports: that the approach is merely rebranding that adds no insight; that it has no clear definition and can cover anything, thus simply muddling policy-making; that it militarizes civilian issues; and that it raises excessive hopes through vague lofty talk. Jolly and BasuRay found the criticisms clearly refuted by the various national studies. They propose that the approach described earlier-direct attention to the diverse factors and threats that in combination determine the degrees of fulfilment and vulnerability of basic needs, rights and values of ordinary people in their particular and diverse circumstances-added distinctive and important insights.

The recent follow-up study (Gomez et al. 2013) reviews a sample of over twenty more such Human Development Reports, including again five reports which Jolly and Basu Ray (2006: 31) had found to be particularly methodologically and/or substantively enlightening. Most of the reports are listed in Table 3 (some of the reviewed reports were not yet completed or not publicly released). Findings from this new study parallel those of Jolly and Basu Ray. Many of the Reports constitute strong examples of applying principles in human security thinking to a specific time and place; for example, the reports for Chile (1998), Latvia (2003), Afghanistan (2004), Costa Rica (2005), the Arab Region (2009), Benin (2011) and Africa (2012), covering a variety of themes. ${ }^{x}$ A number of design options have emerged: the 'comprehensive mapping' type of report that tries to survey all the major types of threat to human security in a particular time and place; reports that centre on crime and physical security; reports that centre on Statebuilding; and reports that take up a single specific type of threat or threatened value that has priority relevance in the particular country or region and period-for example, food security as studied in the Africa regional report of 2012. (See Table 2.) Studies of climate change, its human implications and the options for strengthening adaptive capacity, could form a fifth category, but within the UNDP system they have so far been labelled separately as climate or environment studies not human security studies. 
Table 2. Categorization of some of the National Human Development Reports that have explicitly adopted a human security theme. (Based on Gomez et al. 2013)

\begin{tabular}{|c|c|c|c|}
\hline $\begin{array}{l}\text { COMPREHENSIVE } \\
\text { FOCUS }\end{array}$ & \multicolumn{3}{|c|}{ NARROWER FOCUS (three of the possible variants) } \\
\hline $\begin{array}{l}\text { Investigation of the } \\
\text { context-specific range of } \\
\text { primary threats to primary } \\
\text { values, done without } \\
\text { restriction in terms of how } \\
\text { to organize security } \\
\text { provision }\end{array}$ & $\begin{array}{l}\text { Focus on one } \\
\text { priority set of threatened } \\
\text { values: 'citizen security', } \\
\text { often with main attention } \\
\text { given to use of } \\
\text { conventional security } \\
\text { instruments }\end{array}$ & $\begin{array}{l}\text { Focus on a priority } \\
\text { threatened means: the } \\
\text { State }\end{array}$ & $\begin{array}{l}\text { Focus on one or two } \\
\text { selected, context-specific } \\
\text { threatened values or } \\
\text { primary threats, without } \\
\text { restriction in terms of } \\
\text { how to organize security } \\
\text { provision }\end{array}$ \\
\hline  & $\begin{array}{ll}\text { 'Citizen security' reports } \\
\quad \text { Caribbean (2012) } \\
\quad \text { Costa Rica (2005) } \\
\text { Bhilippines (2005) } \\
\text { Bangladesh (2002) }\end{array}$ & $\begin{array}{l}\text { State-building reports } \\
\quad \begin{array}{l}\text { Afghanistan (2004) } \\
\text { of Congocratic Republic (2008) }\end{array} \\
\quad \begin{array}{l}\text { Occupied Palestinian } \\
\text { Territories (2009/10) }\end{array}\end{array}$ & $\begin{array}{l}\text { Lead-challenge driven } \\
\text { reports } \\
\quad \text { Africa (2012) } \\
\quad \text { Chile (1998) } \\
\quad \text { Macedonia (2001) } \\
\quad \text { Senegal (2010) } \\
\quad \text { Uruguay (2012/13) }\end{array}$ \\
\hline
\end{tabular}

Much work has appeared on human security and climate change, including in the GECHS program mentioned earlier and from the UN Institute for Environment and Human Security. It is surveyed in the IPCC's 2014 Assessment Report and in Redclift \& Grasso (2013). In addition, other work on climate governance throws light on operationalization of a human security agenda. A book by Held et al. (2013) surveys climate change governance in twelve countries from three continents. As reported there, China and South Korea are by far the most favourably impressive cases. Each employs its own particular multi-mode combination of governance forms that appears relatively effective for its own context. All the other country cases are, to varying extents, disquieting in terms of the implied ongoing and future damage to human rights, human security and human development from climate change, although most also contain pockets of progress.

Analysis of these cases helps to identify indicators of good climate governance, in addition to the outcome-values criteria of contribution towards human security and human rights. Procedural values about the ways in which things should be done-such as transparency, accountability, deliberation, prudence and precaution-may contribute to achievement of the outcome values but are considered anyway good in themselves. Humphreys (2009) elaborates 
on some important procedural values in relation to climate change governance: rights to information, public participation and effective remedy, as stated in the 1948 Universal Declaration and the 1966 Covenant on Civil and Political Rights. These rights are considerably elaborated in the European Union's 1998 Aarhus Convention, which Humphreys identifies as a major potential resource for improving climate change governance.

Instrumental values have no inherent value but their achievement contributes towards the achievement of outcome values. Our earlier discussion implies that social and spatial disaggregation in research and statistics and openness to broad sources of information and to multiple perspectives are important instrumental values here; institutional diversity probably contributes towards them (Poppim 2012). Held et al.'s country cases suggest several other relevant instrumental objectives, including two that are particularly important for promotion of human security: again, wide societal involvement in climate strategy preparation (as evident in South Korea), plus investment in local capacities (done on a huge scale in China). ${ }^{x i}$

Parthasarathy (2013: 52) notes how 'the urban poor are rarely consulted in the making of disaster management plans' in Asia, as elsewhere, and how such plans ignore the poor's distinctive and greater vulnerabilities, especially those of low-income migrants and the homeless. Migrants in particular have typically very little voice, yet they form a huge proportion of the populations of the metropolises of Asia, Africa and Latin America, have specific problems including as victims of prejudice and locational marginalization, and can --by virtue of their work roles, mobility patterns and residential super-density-- become major carriers of climatesensitive diseases. Exploring these sorts of needs and risks, via 'participatory vulnerability mapping and risk assessments' (Parthasarathy 2013: 57), is typically neglected because of planner preference for imported 'state-of-the-art' techno-centric approaches, and through habits of centralist authority.

Elliot remarks that: 'Climate security strategies for building social resilience need to be people-centred not just people-oriented. ... Social resilience requires adaptation strategies and institutions that are inclusive and transparent' (Elliott 2013: 166), and that this in turn requires a rights-based logic, to ensure inclusion rather than leaving it as an optional extra for policymakers. 'A meaningful human security approach to climate change must... [challenge] the closed and top-down nature of traditional regimes of security policy-making and implementation' (Elliott 2013: 173).

Numerous further issues arise in operationalisation: in elaborating methods; in establishing partnerships with existing approaches that already contain relevant methods, besides human rights work, such as empowerment approaches; and in evolving skills and procedures for the 'boundary work' that human security thinking leads us into, crossing conventional sectoral and professional boundaries. This sort of exploration is underway in many contexts, not least in work on violence and peace-building (e.g., Martin \& Owen 2013), 
international migration (e.g. Truong et al. 2014), gender and livelihoods (Tripp et al. 2013), and global environmental change in general (Mathew et al. 2010).

\section{Conclusion: Human Security Analysis and the Social Quality Approach}

I have suggested earlier (Gasper 2011a) that partnership between the social quality approach and work on human security and human development would be feasible and worthwhile. It would also be wise for social quality analysis, rather than to attempt to be a self-contained mega-theory, advised Phillips (2011). The approaches are compatible in several ways. The concept of social quality corresponds to the conditions necessary for personal well-being, noted Therborn (2001); each approach understands well-being as multi-dimensional and as involving reasoned agency; and each contains 'an open or implicit realisation that every entity is a nexus of relations' (Gasper et al. 2013: 24). Human security analysis, like Sen's entitlements analysis that helped create it (Sen 1981), focuses on the multiple patterns of relationships which determine or block individuals' access to valued functionings, in particular their access to satisfiers of basic needs and on the stability or instability of this access. It combines a focus on individuals, reflecting respect for each person's dignity and importance, with a focus on the nexus of relations. This makes human security analysis social in character, not just human in focus; indeed it makes it socio-ecological (Berkes, Colding, Folke 2001) and not only social. This is strongly evident in studies like O'Brien \& Leichenko (2008) or Brauch et al. (2009).

The present paper has referred to some of this now extensive experience in using human security ideas in many sectors and countries. It leads to the suggestion that the human security approach is fulfilling some of the central aspirations of social quality theory, in which: 'The social'...is [understood as] an outcome of the interaction between people (constituted as actors) and their constructed and natural environment, summarized as the "productive and reproductive interrelationships of people in everyday life" ' (vd Maesen and Walker 2014:7). Social quality analysis adds valuable refinement but is not fundamentally different or superior; and it could in isolation become preoccupied with static snapshots of societal conditions rather than with exploring societal dynamics and priority threats (Gasper 2011a; cf. Beck 1992, Urry 2014). To be able to contribute more strongly in governance, social quality analysis could be well advised to investigate ways to partner with and to deepen human security research.

Human security analysis helps us to identify and understand the patterns of impact on, and threats to, fulfilment of people's needs and rights. It then provides a partial basis for policy analyses to design principled and relevant responses. While a human security approach contributes especially to (re)orientation of governance, agenda (re)setting, and evaluation, it too is not a self-contained package of answers to everything. Partnership with social quality analysis, to draw on the latter's insights into the construction of the social and its sister work on measurement and monitoring, can be of mutual benefit. 


\section{REFERENCES}

Ahmed, F., 2007. Statement by Honorable Chief Adviser of the Government of the People's Republic of Bangladesh at the High-level Event on Climate Change, New York, 24 September 2007.

Annan, K., 2006. Statement on Human Rights Day 2006 by UN Secretary-General. http://www.un.org/democracyfund/XNewsHumanRightsDay.htm

Barnett, J., 2011. Human Security. In J. Dryzek, R. Norgaard, D. Schlosberg (eds.), The Oxford Handbook of Climate Change and Society, New York: Oxford University Press; 267-277.

Beck, U. 1992. Risk Society. London: SAGE.

Beetham, D., 2004. Towards a Universal Framework for Democracy Assessment. Democratization, 11(2), 1-17.

Beetham, D.; D. Boyle, 1996. Democracy: 80 Questions and Answers. Delhi: National Book Trust, for UNESCO.

Beetham, D.; E. Carvalho; T. Landman; D. Weir, 2008. Assessing the Quality of Democracy: A Practical Guide. Stockholm: International Institute for Democracy and Electoral Assistance. http://www.idea.int/publications/aqd/loader.cfm?csModule=security/getfile\&pageid=28399

Berkes, F., Colding, J., and Folke, C. 2001. Linking Social-Ecological Systems. Cambridge: Cambridge University Press.

Brauch, H.G., Ú. Oswald Spring, J. Grin, C. Mesjasz, P. Kameri-Mbote, N. Chadha Behera, B. Chourou, H. Krummenacher (Eds.). 2009. Facing Global Environmental Change: Environmental, Human, Energy, Food, Health and Water Security Concepts. Berlin: Springer.

Burgess, J.P., et al., 2007. Promoting Human Security: Ethical, Normative and Educational Frameworks in Western Europe, Paris: UNESCO.

Burnell, P., 2012. Democracy, democratization and climate change. Democratization,19(5), 813-42.

CHS (Commission on Human Security). 2003. Human Security Now, New York. UN Secretary-General's Commission on Human Security.

Colebatch, H.K., 2009. Governance as a conceptual development in the analysis of policy. Critical Policy Studies, 3:1, 58-67.

Dyer, G., 2010. Climate Wars. Oxford: Oneworld Publications.

Elliott, L, 2013. Conclusion - Conditions for enhancing human security. In: L. Elliott and M. Caballero-Anthony (eds.), Human Security and Climate Change in Southeast Asia - Managing risk and resilience. London and New York: Routledge, 165-173.

Estrada-Tanck, D., 2013. Human Security And The Human Rights Of Undocumented Migrants. European Journal of Social Security, 15(2), 151-170.

Gasper, D., 2007. Human Rights, Human Needs, Human Development, Human Security - Relationships between four international 'human' discourses. Forum for Development Studies, 2007/1, 9-43.

Gasper, D. 2011a: The Human and the Social - a comparison of the discourses of Human Development, Human Security and Social Quality. International Journal of Social Quality, 1(1), 91-108.

Gasper, D., 2011b. 'Pioneering the Human Development Revolution': Analysing The Trajectory Of Mahbub UI Haq. J. of Human Development and Capabilities, 12(3), 433-456.

Gasper, D., 2012: Climate Change - The Need For A Human Rights Agenda Within A Framework Of Shared Human Security. Social Research: An International Quarterly of the Social Sciences, 79(4), 983-1014.

Gasper, D. 2013a. The Idea of Human Security. In T. Owen (ed.), 2013, Human Security, 4 volumes, Los Angeles, London, Delhi: SAGE; pp. 325-349 in volume 1.

Gasper, D., 2013b. Concepts of Human Security. In M. Martin and T. Owen (eds.), Handbook of Human Security. Abingdon: Routledge, pp. 28-42.

Gasper, D., 2015. The Ethics of Economic Development and Human Displacement. In G. DeMartino, D. McCloskey, eds., The Oxford Handbook of Professional Economic Ethics. New York: Oxford University Press. Published online at: DOI: 10.1093/oxfordhb/9780199766635.013.023, October 2014.

Gasper, D., and O. Gomez, 2011. Human Security Approaches in Recent Development Thinking and Development Cooperation. Presentation to 'Baltic World Talks: Human Security - towards empowering development', Ministry of Foreign Affairs, Riga, Latvia, June 16-17, 2011. 
Gasper, D., and O.A. Gomez. 2014: Evolution of thinking and research on human security and personal security 1994-2013. Occasional Paper, Human Development Report Office, New York: UNDP. http://hdr.undp.org/en/content/evolution-thinking-and-research-human-and-personal-security-1994-

2013. Also in K. Malik (ed.), Safeguarding Human Progress: Reducing Vulnerabilities, Building Resilience, New York: UNDP, pp. 365-401.

Gasper, D., L. van der Maesen, T-D. Truong, A. Walker. 2013. Connecting 'Human' and 'Social' Discourses: The Human Development, Human Security, and Social Quality Approaches. In Enhancing Capabilities - The Role of Social Institutions, eds. H-U. Otto and H. Ziegler; Opladen \& Farmington Hills: Barbara Budrich Publishers; pp. 13-38. Also at: repub.eur.nl/pub/50570/Metis_195150.pdf.

Giddens, A., 2009. The Politics of Climate Change. Cambridge: Polity.

Gilman, N.; D. Randall; P. Schwartz, 2011. Climate Change and 'Security'. In J. Dryzek, R. Norgaard, D. Schlosberg (eds.), The Oxford Handbook of Climate Change and Society, New York: Oxford University Press; 251-266.

Glasius, M., and M. Kaldor, 2005. Individuals first: a human security doctrine for the European Union. Internationale politik und gesellschaft, 2005 (1), 62-84.

Gomez, O., 2011. Introducing the "Human" into Philippine Security Discourses: Convergence or Dialogue? Kasarinlan: Philippine Journal of Third World Studies, 26 (1-2).

Gomez, O., 2012. What is a human security project? The experience of the UN Trust Fund for Human Security. Global Change, Peace \& Security, 24:3, 385-403.

Gomez, O.; D. Gasper; Y. Mine. 2013. Good Practices in addressing human security through Human Development Reports. Occasional Paper, Human Development Report Office, New York: UNDP. http://hdr.undp.org/sites/default/files/good practices.pdf

Haq, M. ul, 1999. Reflections on Human Development (2nd edition). Delhi: Oxford University Press.

Hastings, D., 2010. Human Security Index 2.0. http://www.humansecurityindex.org/

Held, D., C. Roger, E-M. Nag (eds.). 2013. Climate Governance in the Developing World. Cambridge: Polity Press.

Hulme, M., 2009. Why We Disagree About Climate Change, Cambridge: Cambridge University Press.

Humphreys. S., ed. 2009. Human Rights and Climate Change. Cambridge Univ. Press.

IPCC (Intergovernmental Panel on Climate Change). 2012. Managing the Risks of Extreme Events and Disasters to Advance Climate Change Adaptation. http://www.ipcc-wg2.gov/SREX/.

IPCC 2014. Climate Change 2014: Impacts, Adaptation and Vulnerability. http://www.ipcc.ch/report/ar5/

Jolly, R., and D. Basu Ray, 2006. The Human Security Framework and National Human Development Reports. NHDR Occasional Paper 5, New York: UNDP.

Jolly, R., and D. Basu Ray, 2007. Human Security - national perspectives and global agendas., J. of International Development, 19(4), 457-472.

Jolly, R.; L. Emmerij; and T.G. Weiss, 2009. UN Ideas That Changed the World, Bloomington IN: Indiana University Press.

Khan, A.R.; A.K.M. Abdus Sabur, 2011. Human Security Index for South Asia. Dhaka: The University Press.

Leichenko, R., and K. O’Brien, 2008. Environmental Change and Globalization: Double Exposures. New York: Oxford University Press.

Lipschutz, R., and C. McKendry, 2011. Social Movements and Global Civil Society. In J. Dryzek, R. Norgaard, D. Schlosberg (eds.), The Oxford Handbook of Climate Change and Society, New York: Oxford University Press; 369-383.

MacFarlane, N., and Khong Y.F., 2006. Human Security and the UN - A Critical History, Bloomington, IN: University of Indiana Press.

Maesen, L. van der, and A. Walker. The Development of Social Quality between 1994 and 2014. Working Paper 13, The Hague: International Association on Social Quality.

Martin, M. and T. Owen (eds.). 2013. Handbook of Human Security. Abingdon: Routledge

Matthew, R., et al. eds., 2010. Global Environmental Change and Human Security, Cambridge, MA: M.I.T. Press.

Moran, D. (ed.). 2011. Climate Change and National Security: A Country-level Analysis. Washington, DC, USA: Georgetown University Press.

Nussbaum, M., 1997. Cultivating Humanity. Cambridge, MA: Harvard University Press. 
Parthasarathy, D., 2013. Risk, Vulnerability and Resilience - Climate change and the urban poor in Asia. In: : L. Elliott and M. Caballero-Anthony (eds.), Human Security and Climate Change in Southeast Asia Managing risk and resilience. London and New York: Routledge, 43-61.

Phillips, D. 2011. The Individual and the Social: a Comparative Study of Approaches to Quality Of Life. International Journal of Social Quality, 1(1), 71-89.

Puppim de Oliveira, J.A., ed. 2012. Green Economy and Good Governance for Sustainable Development. Tokyo: United Nations University.

Redclift, M. and M. Grasso, eds., 2013. Handbook of Climate Change and Human Security, Cheltenham: Edward Elgar. Routledge, P., 2011. Translocal Climate Justice Solidarities. In J. Dryzek, R. Norgaard, D. Schlosberg (eds.), The Oxford Handbook of Climate Change and Society, New York: Oxford University Press; 384-398.

Saferworld. 2008. Human Security in Bangladesh. London: Saferworld.

Sen, A. 1981. Poverty and Famines. Oxford: Oxford University Press.

Sen, A. 1999. Development as Freedom. New York: Oxford University Press.

Snidal, K., and Abbott, D. 2009. The governance triangle. In W. Mattli \& N. Woods (eds.), The Politics of Global Regulation. Princeton, NJ: Princeton University Press.

Therborn, G. 2001. On the Politics and Policy of Social Quality. Pp. 19-30 in Social Quality: A Vision for Europe, W. Beck et al. eds. The Hague: Kluwer Law International.

Tripp, A.M., M.M. Ferree, C. Ewig, eds, 2013, Gender, Violence, and Human Security: critical feminist perspectives. New York: New York University Press.

Truong, T-D., D. Gasper, J. Handmaker, S. Bergh (eds.) 2014. Migration, Gender and Social Justice: Perspectives on human insecurity. Heidelberg: Springer. Open-access: http://link.springer.com/book/10.1007/978-3-64228012-2

UNDP, 1994. Human Development Report 1994, New York: Oxford University Press.

UNDP, 2003. Latvia Human Development Report: 2002-2003: Human Security. http://hdr.undp.org/en/reports/nationalreports/europethecis/latvia/name,3194,en.html

UNDP, 2011. Sécurité Humaine et Développement Humain au Bénin. http://hdr.undp.org/en/reports/national/africa/benin/name,18986,en.html

UNESCO, 2008. Human Security - Approaches And Challenges. Paris: UNESCO.

UNTFHS 2009. Human Security in Theory and Practice. New York: United Nations Trust Fund for Human Security.

United Nations General Assembly, 2012. Resolution on: Follow-up to paragraph 143 on human security of the 2005 World Summit Outcome. Adopted on 10 September 2012. A/RES/66/290

United Nations Secretary General. 2010. Report to UN General Assembly, on Human Security. A/64/701.

Urry, J., 2014. Thinking Society Anew. Reprinted in: U. Beck, Ulrich Beck: Pioneer in Cosmopolitan Sociology and Risk Society. Heidelberg: Springer. Pp. v-xi.

Weiss, T.G., T. Carayannis, L. Emmerij, R. Jolly. 2005. UN Voices: the struggle for development and social justice. Bloomington, IN: Indiana University Press.

World Bank, 2010. World Development Report 2010: Development and Climate Change. Washington DC: World Bank.

\footnotetext{
' Forthcoming in International J. of Social Quality, 4(2), 2014. This paper grows out of a keynote talk to a Conference on Governance and Public Service Transformation, Dhaka, 7-9 December 2012, organized by the Affiliated Network for Social Accountability (ANSA), South Asia Region, and from comments received there. Parts of the paper build on a version in the ANSA conference proceedings, which has been revised and greatly extended in the light of comments and suggestions including from the journal editors.

ii Resolution 66/290. http://www.un.org/ga/search/view doc.asp?symbol=\%20A/RES/66/290

iii See the books from the UN Intellectual History Project, e.g.: Weiss et al. 2005; Jolly et al. 2009.

iv 'In the 2007 Cyclone Sidr [in Bangladesh] some people died who declined to go to shelters because that would leave their animals unattended, since some who went to shelters during a previous warning were robbed at home.' (Saferworld 2008: p.iii).

$\checkmark$ Unlike in many democracy assessments, which select criteria ad hoc, IDEA 'derive our assessment norms from clearly defined democratic principles': popular control (direct or mediated), and equality between citizens in relation to public decisions (Beetham 2004:6). IDEA tries to justify its universal framework (of principles, not
} 
structures), by reference to worldwide support for such principles, to normative philosophy and to some claimed universals about human nature: 'it is human equality that makes democracy desirable, human capacities that make it possible, and all-too human limitations that make it necessary' (ibid:12). Its criteria include economic and social rights: as the outcome that people expect from effective democracy and as its necessary preconditions. Choices in interpreting and balancing the different, partly competing, criteria are made by the national assessment teams, including through explicit consultation and public debate. IDEA rejects reducing democracy assessments to a single index because that oversimplifies, hides vital information, and is misused politically.

vi Anthony Giddens' book on climate change similarly repeatedly mis-spelled Darfur, as Dafur (2009: 205).

vii Bangladesh is mentioned once, with reference to an NGO project to help 'vulnerable delta communities' (Hulme, 2009: 258).

viii In The Independent newspaper, June 20, 2008; quoted by Dyer (2010:56).

ix Parts of the rest of this section draw on Gasper \& Gomez (2011).

${ }^{x}$ The national and regional Human Development Reports are available on-line, e.g. via

http://hdr.undp.org/en/reports/national/ and http://hdr.undp.org/en/regional-reports

${ }^{x i}$ Other relevant indicators or instrumental objectives in climate change governance include: 1 . National awareness of vulnerability, responsibilities, and of opportunities via reorientation in response to climate change; 2 .

Elaboration of a policy vision; 3 . Relevance and clarity of policy focus (e.g. on adaptation when one is a highly vulnerable low-emitter); 4. Setting of targets (as done comprehensively in China); 5 . Political and legal commitment behind the targets and talk; 6 . Ability to translate commitment into action; 7. Feeling of domestic ownership of the policy direction; 8. Preparation of policies on energy efficiency; 9. Provision of incentives for change; 10. Creation/empowerment of agencies with specified duties; 11. Clarity of inter-agency responsibilities; 12. Coordination amongst international agencies; 13 . Investment in new energy sources; 14 . Commitment of resources. 